\title{
HEADSPACE VOLATILES OF SELECTED MELON, PEAR AND CARROT CULTIVARS
}

\author{
UDC $[635.611+635.13+634.13]: 577.13$
}

\section{Olga P. Jovanović, Gordana S. Stojanović}

\author{
Department of Chemistry, Faculty of Science and Mathematics,
} University of Niš, Serbia

\begin{abstract}
Herein, we report on the results of solvent- and sorbent-free HS-GC-MS (headspace - gas chromatography - mass spectrometry) analysis of the headspace volatiles (HSVs) of fruits of cultivated melon (Cucumis melo L. cultivar "ananas dinja" [pineapple melon]) and pear (Pyrus communis L. cultivar "Julska lepotica" [the beauty of July]), as well as of underground parts of carrot (Daucus carota L. cultivar "nantes"). The obtained results are comparable to those of the traditional HS method. The main HSV of melon were 2-methylbutyl acetate (42.9\%), ethyl butanoate (11.4\%), butyl acetate (10.1\%), and methyl 2-methylbutanoate (9.8\%); these are mostly biosynthetically related to amino acids. LOX (lipoxygenase) pathway products, hexanal (32.9\%) and 1-hexanol (20.8\%), and s sesquiterpene hydrocarbon, (E,E)- $\alpha$-farnesene (24.9\%), were found to be the dominant constituents of the pear headspace profile. The dominant HSVs of carrot underground parts were the monoterpenes sabinene (29.2\%) and $\alpha$-pinene (21.5\%).
\end{abstract}

Key words: Cucumis melo L., Pyrus communis L., Daucus carota L., headspace volatiles, $G C-M S$

\section{INTRODUCTION}

In addition to their nutritional importance, fruits and vegetables are valued for their biological/pharmacological (e.g. antioxidant, antibiotic) and/or flavoring properties [1]. These beneficial assets are often connected to the presence of different volatile secondary metabolites [2]. Fruit/vegetable volatile secondary metabolic profile is affected by numerous factors including the genetic makeup, degree of maturity, environmental conditions, postharvest handling or storage. Whether they are present in intact fruit tissue

Received July $9^{\text {th }}, 2014$; revised August $5^{\text {th }}, 2014$; accepted August $20^{\text {th }}, 2014$

Corresponding author: Srđan Đ. Stojanović

Department of Chemistry, Faculty of Science and Mathematics, University of Niš, Višegradska 33, 18000 Niš, Serbia

E-mail: stgocaus@yahoo.com 
or produced during (mechanical) tissue disruption, fruit/vegetable (aroma) volatiles are sometimes referred as "primary" or "secondary" compounds [3].

The outcome of chemical analyses of fruit/vegetable volatile secondary metabolic profile (e.g. mutual ratio of primary and secondary compounds) depends on sample's preparation procedure or analytical method employed. For example, during steam distillation, sample's composition could alter due to the thermal degradation of its primary compounds [4]. Contrary to that, headspace technology usually employs milder experimental conditions. Nonetheless, the usual way of conducting headspace extraction of volatile compounds includes their adsorption on the selected sorbent (fiber), followed by elution with a suitable solvent and, finely, solvent removal (e.g. by evaporation under vacuum or in the stream of nitrogen) [4]. The serious shortcoming of this approach is that during the mentioned, sometimes time-consuming operations, a sample might be contaminated, some constituents might undergo chemical transformations, while those of high volatility might be lost.

The main goal of this study was to provide additional data on the volatile secondary metabolic profile of the fruits of cultivated melon (Cucumis melo L. cultivar "ananas dinja" [pineapple melon]) and pear (Pyrus communis L. cultivar "Julska lepotica" [the beauty of July]), as well as of the roots of carrot (Daucus carota L. cultivar "nantes"). In order to minimize the possible risk of samples' contamination/alteration, we have applied mild solvent- and sorbent-free headspace method for the isolation of the volatile metabolites (headspace volatiles, HSVs), which were further analyzed using gas chromatography-mass spectrometry. To the best of our knowledge, this approach was not previously employed for the profiling of melon/peer/carrot aroma compounds.

\section{MATERIALS AND METHODS}

\subsection{Sample preparation}

Appropriate amounts of fully ripe, undamaged (e.g. without bruising and compression damage) fruits of $C$. melo $(5 \mathrm{~kg})$ and $P$. communis $(1 \mathrm{~kg})$, as well as of roots of $D$. carota $(1 \mathrm{~kg})$ were bought at the local market "Tvrđava", Niš, in July 2013. Prior to further treatment, all samples were washed under a strong stream of water. In the case of melon and pears, the fruits (without the stem ends and any remains of the flowers) were peeled, cut longitudinally into quarters, and cleaned of seeds and placental tissue; carrot roots were processed as is. The samples were chopped in a blender and $500 \mathrm{mg}$ of each of the resulting pulps was transferred into separate $20 \mathrm{~mL}$ HS (head space) vial. The vial was immediately placed into the GC-MS-MS tray and thermostated at $80{ }^{\circ} \mathrm{C}$ for 20 min during which the sample was shaken (5 sec shaking cycles with $2 \mathrm{sec}$ pauses). Five hundred $\mu \mathrm{L}$ of headspace vapor was drawn out from the vial using a gas-tight syringe $\left(90{ }^{\circ} \mathrm{C}\right)$, and injected into the GC instrument by Combi PAL auto sampler. The split ratio was set to 10:1 and the temperature of the transfer line was $75^{\circ} \mathrm{C}$.

Preparation of the samples was conducted at room temperature and atmospheric pressure and the possible influence of atmospheric oxygen was disregarded. 
Table 1 Chemical composition (\%) of Cucumis melo (melon), Pyrus communis (pear) and Daucus carota (carrot) head space volatiles (HSV) and odor characteristics of the HSV constituents

\begin{tabular}{|c|c|c|c|c|c|c|}
\hline $\mathrm{RI}^{\mathrm{a}}$ & $\mathrm{AI}^{\mathrm{b}}$ & Compound & Melon & Pear & Carrot & Odour $^{c}$ \\
\hline 764 & 762 & Pentanol & $-^{d}$ & 0.6 & - & $\begin{array}{l}\text { pungent, fermented, bready, yeasty, } \\
\text { fusel, winey and solvent-like }\end{array}$ \\
\hline 770 & $755^{\mathrm{e}}$ & Ethyl isobutanoate & 0.2 & - & - & $\begin{array}{c}\text { resembling orange juice or pineapple } \\
\text { odor }\end{array}$ \\
\hline 781 & 761 & Isobutyl acetate & 7.9 & - & - & odor of hyacinth and roses \\
\hline 784 & $780^{\mathrm{e}}$ & Methyl 2-methylbutanoate & 9.8 & - & - & fruity type \\
\hline 802 & 801 & Hexanal & - & 32.9 & 7.5 & green, leafy \\
\hline 802 & 802 & Ethyl butanoate & 11.4 & - & - & $\begin{array}{l}\text { fruity, orange } \\
\text { pineapple }\end{array}$ \\
\hline 810 & $810^{\mathrm{e}}$ & Propyl propanoate & 0.1 & - & - & distinctly fruity, tinged pineapple \\
\hline 814 & 807 & Butyl acetate & 10.1 & 4.1 & - & ethereal \\
\hline 849 & $842^{\mathrm{e}}$ & Ethyl 2-methylbutanoate & 7.4 & - & - & $\begin{array}{l}\text { etheric, unspecific, pleasant apple } \\
\text { note at extreme dilution }\end{array}$ \\
\hline 852 & 846 & (E)-2-Hexenal & - & 7.1 & - & grassy \\
\hline 866 & 863 & 1-Hexanol & - & 20.8 & - & herbaceous, woody \\
\hline 876 & 869 & Isopentyl acetate & 0.8 & - & - & odor of banana \\
\hline 878 & 875 & 2-Methylbutyl acetate & 42.9 & 0.2 & - & fruity odor like bananas \\
\hline 915 & 911 & Amyl acetate & 0.4 & - & - & banana or pear like \\
\hline 929 & 924 & $\alpha$-Thujene & - & - & 0.2 & terpeny note \\
\hline 936 & 932 & $\alpha$-Pinene & - & - & 21.5 & piney \\
\hline 978 & 969 & Sabinene & - & 1.8 & 29.2 & $\begin{array}{l}\text { oily, citrus, tropical fruity, terpeny } \\
\text { note }\end{array}$ \\
\hline 981 & 974 & $\beta$-Pinene & - & - & 3.5 & piney \\
\hline 1002 & 997 & Ethyl hexanoate & 0.4 & - & - & fruity-apple \\
\hline 1006 & 998 & n-Octanal & - & - & 0.4 & strong fruity \\
\hline 1008 & 1002 & $\alpha$-Phellandrene & - & - & 0.1 & fresh-citrusy, peppery- woody/minty \\
\hline 1009 & 1004 & (Z)-3-Hexenyl acetate & 0.5 & - & - & green type \\
\hline 1015 & 1007 & Hexyl acetate & 5.2 & 0.3 & - & apple, floral, fruity \\
\hline 1028 & 1020 & $p$-Cymene & - & - & 5.6 & terpeny note \\
\hline 1032 & 1024 & Limonene & - & - & 3.7 & orange \\
\hline 1062 & 1054 & $\gamma$-Terpinene & - & - & 1.7 & lemon odor \\
\hline 1091 & 1086 & Terpinolene & - & - & 14.4 & piney \\
\hline 1097 & 1088 & Methyl benzoate & 0.5 & 1.2 & 0.4 & strong, balsamic \\
\hline 1167 & 1157 & Benzyl acetate & 0.3 & - & - & fruity, strawberry, \\
\hline 1381 & 1383 & Isobornyl propanoate & 1.5 & 4.1 & 0.9 & balsamic type \\
\hline 1429 & 1417 & (E)-Caryophyllene & - & - & 10.2 & sweet, spicy \\
\hline 1463 & 1452 & $\alpha$-Humulene & - & - & 0.2 & woody \\
\hline \multirow[t]{2}{*}{1511} & 1505 & $(E, E)$ - $\alpha$-Farnesene & - & 24.9 & - & green apple \\
\hline & & Total & 99.4 & 98.0 & 99.5 & \\
\hline
\end{tabular}

${ }^{\mathrm{a}} \mathrm{RI}$ - experimental linear retention indices relative to $\mathrm{C}_{8}-\mathrm{C}_{44}$ alkanes on the HP-5MS [5]; ${ }^{\mathrm{b}} \mathrm{AI}-\mathrm{RIs}$ correspond to those listed in Adams, 2007 [6], if not stated otherwise; ${ }^{\mathrm{c}}$ Odour characteristics adopted from http://en.wikipedia.org; ${ }^{\mathrm{d}}-$ not detected; ${ }^{e}$ - RIs available from NIST Chemistry Webbook (Van Den Dool and Kratz RI, HP-5MS column, temperature ramp), http://webbook.nist.gov [7].

\subsection{GC-MS analysis}

All samples were analyzed in triplicates, using a 7890/7000B GC/MS/MS triple quadrupole system (Agilent Technologies, USA) equipped with a Combi PAL auto sampler and Headspace Upgrade for G6501B-G6509B. The analysis was performed in MS mode. The fused silica 
capillary column HP-5MS (5\% phenylmethylsiloxane, $30 \mathrm{~m}$ x $0.25 \mathrm{~mm}$, film thickness $0.25 \mu \mathrm{m})$ was used. The injector and interface operated at 230 and $300{ }^{\circ} \mathrm{C}$ respectively. The carrier gas was helium with a flow of $1.0 \mathrm{~mL} \mathrm{~min}^{-1}$.

The temperature was rised from 50 to $290{ }^{\circ} \mathrm{C}$ at a heating rate of $4{ }^{\circ} \mathrm{C} \mathrm{min}{ }^{-1}$. Post run: back flash for $1.89 \mathrm{~min}$, at $280{ }^{\circ} \mathrm{C}$, with helium at $50 \mathrm{psi}$. MS conditions were as follows: ionization voltage of $70 \mathrm{eV}$, acquisition mass range $50-650$, scan time $0.32 \mathrm{~s}$. The percentage composition was computed from the TIC peak areas. Constituents were identified by comparison of their linear retention indices (relative to $\mathrm{C}_{8}-\mathrm{C}_{44}$ alkanes on the HP-5MS column) [5] with literature values [6,7], and their MS with those from Wiley 6, NIST02 [8] and Mass Finder 2.3 databases. This was done using AMDIS software (the Automated Mass Spectral Deconvolution and Identification System, Ver. 2.1, DTRA/NIST, 2011).

\section{RESULTS AND DISCUSSION}

The results of HS-GC-MS analyses of melon and pear fruits and carrot roots are given in the Table 1. Table 1 also lists odor characteristics of melon/pear/carrot volatiles. The employed HS-GC-MS method enabled the identification of 16 melon, 11 pear and 15 carrot headspace volatile compounds (99.4, 98.0 and $95.5 \%$ of the total HSV, respectively). All melon volatiles were esters of acetic, propanoic, butanoic, isobutanoic, 2-methylbutanoic, hexanoic and benzoic acid. The most abundant HSV in this sample was 2-methylbutyl acetate $(42.4 \%)$, which accounted for almost half of total melon headspace volatiles. Significant amounts of ethyl butanoate $(11.4 \%)$, butyl acetate $(10.1 \%)$, and methyl 2methylbutanoate $(9.8 \%)$ were also detected. This is in agreement with the previous results on melon volatiles [9]. 2-Methylbutyl acetate has been identified as the dominant aroma compound (solid-phase microextraction) of three cultivars of muskmelon [9]. In addition high relative amounts of sulfur-containing esters were detected in cantaloupe, honeydew and Galia melons. Cantaloupe melons were associated with sweet, floral and fruity aromas and a persistent aftertaste; Galia melons possessed the strongest cucumber-like flavours; honeydew melons were of cucumber aroma and sweet flavor [9]. According to herein presented results (Table 1), cultivar "ananas dinja" has completely unique flavor and aroma (fruity odor like bananas, ethereal, orange, pineapple). Biosynthetic precursors of the main melon's HSV esters are most probably corresponding amino acids (e.g. isoleucine in the case of esters of 2-methylbutanoic acid or 2-methylbutan-1-ol), which could be converted into $\alpha$-keto acid by deamination/transamination; subsequent decarboxylation/reductions/oxidations and/or esterifications lead to esters of short chain fatty acids/alcohols [10].

Unlike melon, pear's headspace volatile profile contained much lower amount of esters $(9.9 \%$ in total). Three main pear HSVs were green leaf volatiles hexanal $(32.9 \%)$ and 1-hexanol (20.8\%), as well as sesquiterpene hydrocarbon $(E, E)$ - $\alpha$-farnesene $(24.9 \%)$. This is not in agreement with the previous study regarding volatiles of European pear: the chief volatiles of this cultivar were methyl and hexyl decadienoate, hexyl acetate, 2methylpropyl acetate, butyl acetate, butyl butanoate, pentyl acetate, and ethyl hexanoate [3]. Both 1-hexanol and hexanal are biosynthetically related to fatty acids (mainly C18:2 and C18:3). Unsaturated fatty acids undergo oxidation via so-called LOX (lipoxygenase) pathway-this is triggered by cell membrane disruptions-yielding (mainly) C6-C9 aldehydes and alcohols, known as green leaf volatiles [11]. 
The main carrot root HSVs were mono- and sesquiterpenes (91.3\% of the total): sabinene $(29.2 \%)$, $\alpha$-pinene $(21.5 \%)$, terpinolene $(14.4 \%)$ and $(E)$-caryophyllene $(10.2 \%)$. These are biosynthetically derived from the C5 precursor isopentenyl diphosphate (IPP) and its allylic isomer dimethylallyl diphosphate (DMAPP) [3]. Herein presented results on carrot volatiles are in general agreement with those reported by Kjeldsen et al., 2001 [12], except for they have reported $\gamma$-bisabolene as one of the major volatiles of carrot [12]. The mention dissimilarity might be due to the differences in experimental procedures, or nature/origin of studied cultivars.

\section{CONCLUSIONS}

The herein presented results indicate that in the three studied commercial fruit and vegetable cultivars, different biochemical pathways lead to HSV compounds: the key volatiles of melon were derived from amino acids; pear HSVs were mainly products of LOX pathway; the dominant carrot volatiles were mono- and sesquiterpenes. Taking into account that they belong to completely different plant families, this is not surprising. Nonetheless, it still underlines the diversity of plant (secondary) metabolism. The herein presented results are in general agreement with those provided by traditional HS methods. Nonetheless, sorbent- and solvent-free HS-GC-MS method could be considered as less time-consuming and cheaper.

Acknowledgement. Financial support of the Ministry of Education, Science and Technological Development of Serbia (Project No. 172047) is gratefully acknowledged.

\section{REFERENCES}

1. L.A. Terry, Health-promoting properties of fruit and vegetables, Cambridge, Wallingford, UK, 2011.

2. N.S. Radulović, P.D. Blagojević, Z.Z. Stojanović-Radić, N.M. Stojanović, Antimicrobial plant secondary metabolites: structural diversity and mechanism of action, Current Medicinal Chemistry, 20 (7), 932-952 (2013)

3. M.A.M. El Hadi, F. Zhang, F. Wu, C. Zhou and J. Tao, Advances in Fruit Aroma Volatile Research, Molecules, 18 (7), 8200-8229 (2013).

4. D.D. Rowan, Volatile metabolites, Metabolites, 1 (1), 41-63 (2011).

5. H. Van Den Dool and P.D. Kratz, A generalization of the retention index system including linear temperature programmed gas-liquid partition chromatography, Journal of Chromatography A, 11, 463471 (1963)

6. R.P. Adams, Identification of essential oil components by gas chromatography/mass spectroscopy, Allured Publishing Corporation, Illinois, 2007.

7. National Institute of Standards and Technology, NIST Chemistry WebBook, Nist Standard Reference database Website. http://webbook.nist.gov/chemistry/ 2005.

8. S.E. Stein, National Institute of Standards and Technology (NIST) Mass Spectral Database and Software, Version 3.02, USA 1990.

9. D. Kourkoutas, J.S. Elmore and D.S. Mottram, Comparison of the volatile compositions and flavour properties of cantaloupe, Galia and honeydew muskmelons, Food Chemistry, 97 (1), 95-102 (2006).

10. D.D. Rowan, H.P. Lane, J.M. Allen, S. Fiedler and M.B. Hunt, Biosynthesis of 2-methylbutyl, 2-methyl2-butenyl, and 2-methylbutanoate esters in red delicious and granny smith apples using deuteriumlabeled substrates, Journal of Agricultural and Food Chemistry, 44 (10), 3276-3285 (1996). 
11. C. Gigot, M. Ongena, M.-L. Fauconnier, J.-P. Wathelet, P. Du Jardin and P. Thonart, The lipoxygenase metabolic pathway in plants: potential for industrial production of natural green leaf volatiles, Biotechnologie, Agronomie, Société et Environnement, 14 (3), 451-460 (2010).

12. F. Kjeldsen, L. Christensen and M. Edelenbos, Quantitative Analysis of Aroma Compounds in Carrot (Daucus carota L.) Cultivars by Capillary Gas Chromatography Using Large-Volume Injection Technique, Journal of Agriculture and Food Chemistry, 49 (9), 4342-4348 (2001).

\section{ISPARLJIVI SASTOJCI PLODOVA GAJENE DINJE, KRUŠKE I ŠARGAREPE}

U ovom radu su izloženi rezultati HS-GC-MS (headspace - gasna hromatografija - masena spektrometrija) analize ,headspace” isparljivih sastojaka (HSV) plodova gajene dinje (Cucumis melo L., kultivar ,ananas dinja”), kruške (Pyrus communis L., kultivar „Julska lepotica”) i šargarepe (Daucus carota L., cultivar ,nantes”), i to bez uporebe rasvarača ili sorbenta. Rezultati su uporedivi sa onima dobijenim primenom tradicionalne HS metode. Glavni HSV sastojci dinje su bili 2metilbutil-acetat (42,9\%), etil-butanoat (11,4\%), butil-acetat (10,1\%) i metil-2-metilbutanoat $(9,8 \%)$; uopšteno, ova jedinjenja su u biosintetskom smislu izvedena iz aminokiselina. Dominantni sastojci HS profila kruške bili su heksanal (32,9\%) i 1-heksanol (20,8\%) (proizvodi LOX (lipoksigenaza)

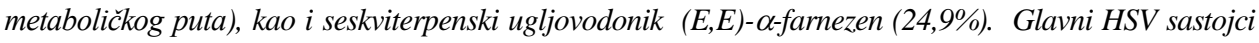
šargarepe su bili monoterpeni sabinen $(29,2 \%)$ i $\alpha$-pinen $(21,5 \%)$.

Ključne reči: Cucumis melo L., Pyrus communis L., Daucus carota L., headspace isparljivi sastojci, $G C-M S$ 